\title{
Research Papers \\ Population Change in a Marine Bird Colony is Driven By Changes in Recruitment
}

\section{Influence du taux de recrutement sur les effectifs d'une colonie d'oiseaux marins}

\author{
$\underline{\text { Anthony J. Gaston }}^{1}$ and Sébastien Descamps ${ }^{2}$
}

\begin{abstract}
The population dynamics of long-lived birds are thought to be very sensitive to changes in adult survival. However, where natal philopatry is low, recruitment from the larger metapopulation may have the strongest effect on population growth rate even in long-lived species. Here, we illustrate such a situation where changes in a seabird colony size appeared to be the consequence of changes in recruitment. We studied the population dynamics of a declining colony of Ancient Murrelets (Synthliboramphus antiquus) at East Limestone Island, British Columbia. During 1990-2010, Ancient Murrelet chicks were trapped at East Limestone Island while departing to sea, using a standard trapping method carried on throughout the departure period. Adult murrelets were trapped while departing from the colony during 1990-2003. Numbers of chicks trapped declined during 1990-1995, probably because of raccoon predation, increased slightly from 1995-2000 and subsequently declined again. Reproductive success was 30\% lower during 2000-2003 than in earlier years, mainly because of an increase in desertions. The proportion of nonbreeders among adult birds trapped at night also declined over the study period. Mortality of adult birds, thought to be mainly prebreeders, from predators more than doubled over the same period. Apparent adult survival of breeders remained constant during 1991-2002 once the first year after banding was excluded, but the apparent survival rates in the first year after banding fell and the survival of birds banded as chicks to age three halved over the same period. A matrix model of population dynamics suggested that even during the early part of the study immigration from other breeding areas must have been substantial, supporting earlier observations that natal philopatry in this species is low. The general colony decline after 2000 probably was related to diminished recruitment, as evidenced by the lower proportion of nonbreeders in the trapped sample. Hence the trend is determined by the recruitment decisions of externally reared birds, rather than demographic factors operating on the local breeding population, an unusual situation for a colonial marine bird. Because of the contraction in the colony it may now be subject to a level of predation pressure from which recovery will be impossible without some form of intervention.
\end{abstract}

RÉSUMÉ. On pense que la dynamique des populations d'oiseaux ayant une longévité accrue est sensible aux changements dans la survie des adultes. Toutefois, lorsque le degré de philopatrie est faible, le recrutement au sein de la métapopulation a peut-être davantage d'effet sur le taux de croissance de la population, même chez les espèces à longévité accrue. Dans le présent article, nous illustrons un cas où les changements d'effectifs d'une colonie d'oiseaux marins semblent être la conséquence des fluctuations du taux de recrutement, au moyen de l'étude de la dynamique de population d'une colonie de Guillemots à cou blanc (Synthliboramphus antiquus) en déclin à l'île Limestone Est en Colombie-Britannique. De 1990 à 2010, de jeunes guillemots ont été capturés sur l'île Limestone Est au moment de quitter la colonie, à l'aide d'une méthode de capture standard utilisée tout au long de la période des départs. Les guillemots adultes ont pour leur part été capturés au moment de leur départ de la colonie, de 1990 à 2003 . Le nombre

${ }^{1}$ Science and Technology Branch, Environment Canada, ${ }^{2}$ Norwegian Polar Institute

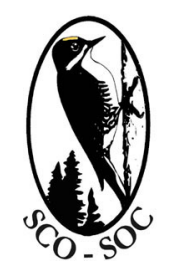

Sponsored by the Society of Canadian Ornithologists and Bird Studies Canada Parrainée par la Société des ornithologistes du Canada et Etudes d'oiseaux Canada

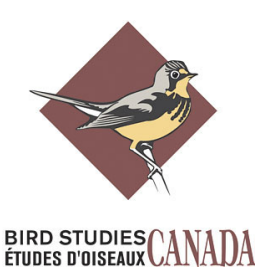


de jeunes capturés a diminué de 1990 à 1995, probablement en raison de la prédation par le raton laveur, puis a augmenté légèrement de 1995 à 2000, pour diminuer de nouveau durant les années subséquentes. Le succès de reproduction était inférieur de 30\% durant les années 2000-2003 comparativement aux années précédentes, principalement à cause d'une hausse du taux d'abandon des sites. La proportion d'individus non nicheurs parmi les adultes capturés la nuit a aussi diminué au cours de la période d'étude. La mortalité des adultes - probablement surtout des prospecteurs - associée à la prédation a plus que doublé pendant la même période. La survie apparente des adultes nicheurs est demeurée constante durant la période 1991-2002 quand l'année suivant celle du baguage était exclue, mais les taux de survie apparente durant la première année suivant le baguage ont baissé et la survie des jeunes âgés de un à trois ans a diminué de moitié durant la même période. Par ailleurs, un modèle matriciel de la dynamique de population a montré que, même dans les premières années de notre étude, l'immigration en provenance d'autres sites de nidification devait être importante, corroborant l'hypothèse selon laquelle la philopatrie est faible chez cette espèce. Le déclin général de la colonie après l'an 2000 était probablement lié à un faible taux de recrutement, comme en témoignait la faible proportion de prospecteurs dans l'échantillon d'oiseaux capturés. Ainsi, la tendance des effectifs dépend du recrutement d'oiseaux hors colonie, et non pas des facteurs démographiques qui agissent dans la population locale, une situation inhabituelle chez un oiseau marin colonial. Étant donné la diminution des effectifs survenue dans la colonie, il se peut que la pression de prédation dont elle fait maintenant l'objet ne lui permette pas de s'en remettre sans intervention.

Key Words: breeding colony, philopatry, population dynamics, recruitment, reproduction, survival, Synthliboramphus antiquus

\section{INTRODUCTION}

Seabird life histories are characterized by relatively low reproductive rates, deferred breeding, and high adult survival (Lack 1963, 1968, Goodman 1974). Consequently, seabirds, especially those feeding away from coastal waters, are clearly "slow species" (Gaillard et al. 1989) or "survivor species" (Saether and Bakke 2000). Population growth rate of "slow" species is usually more sensitive to changes in adult survival than changes in juvenile survival (Gaillard et al. 1989, Saether and Bakke 2000). Nevertheless, juvenile survival may exhibit large temporal variation compared with adult survival (Stearns and Kawecki 1994, Gaillard and Yoccoz 2003), which can greatly affect the population growth rate (Saether and Bakke 2000). We examined the relative role of variation in juvenile and adult survival as well as in breeding parameters, in determining the decline of a breeding colony of a marine diving bird, the Ancient Murrelet Synthliboramphus antiques (decline by $70 \%$ between 1989 and 2006; Lemon 2007).

The Ancient Murrelet is a small alcid that breeds throughout the North Pacific rim. It is an abundant breeder in the islands of Haida Gwaii (Queen Charlotte Islands), Canada, which support about
$50 \%$ of the world population (Gaston 1994). The Ancient Murrelet exhibits a rare breeding strategy, in that hatchlings, usually two, are not fed in the nest but leave after two to three days, make their way to the shore, reunite with their parents at sea, and are reared entirely away from land (Sealy 1976, Gaston 1992).

Monitoring of breeding population of Ancient Murrelets in Haida Gwaii has been carried out for the past two to three decades at several colonies, mainly through periodic line-transect surveys, or by counting burrows in demarcated study plots (Rodway et al. 1988, Lemon 2007, Regehr et al. 2007). More intensive monitoring of a variety of breeding biology parameters and population indices has been carried out by the Laskeek Bay Conservation Society at East Limestone Island, in Laskeek Bay, since 1990 (e.g., Rock and Pattison 2007, 2008).

Ancient Murrelet adults are subject to predation by natural avian (Raven Corvus corax, Bald Eagle Haliaeetus leucocephalus) and mammalian (river otter Lutra canadensis) predators while visiting the colony (Gaston 1992). In addition, the East Limestone Island colony has been subject to periodic predation by raccoons Procyon lotor, an 
introduced species in Haida Gwaii (Rodway 1991, Gaston 1994, Hartman et al. 1997). Based on quadrat sampling of occupied burrows, the population of Ancient Murrelets on East Limestone Island was estimated at 1485 breeding pairs in 1983, 1614 pairs in $1989,1273 \pm 254$ (SE) pairs in 1995, and $509 \pm 132$ (SE) pairs in 2006 (for details of methods see Rodway et al. 1988, Lemon 2007) The decrease since 1989 has caused concern that the colony may soon be extirpated and this study seeks to evaluate potential causes. We examine trends in the breeding population of Ancient Murrelets at East Limestone Island, in relation to changes in several breeding biology parameters and in adult and juvenile survival. We also assess change in relation to known predation events by raccoons. Comparable information for some of the variables measured is available for the period 1984-1989 from studies at an adjacent colony on Reef Island (Gaston 1990, 1992) during a period when the population was increasing.

\section{METHODS}

\section{Study area}

Our study was carried out during 1990-2010 at East Limestone Island (52 54 $\left.28^{\circ} \mathrm{N}, 131^{\circ} 36^{\prime} \mathrm{W}\right)$, situated in Laskeek Bay, Haida Gwaii (Queen Charlotte Islands; Fig.1). At the outset of the study the colony was among the smallest on Haida Gwaii, with 1500 breeding pairs in 1983 (Rodway et al. 1988), compared with colony sizes elsewhere ranging to 60,000 breeding pairs (Rodway 1991). However, the habitat, in coastal evergreen oldgrowth forest within $300 \mathrm{~m}$ of shore, is typical of colonies in this region (Gaston 1992). A larger colony of 5000 breeding pairs is situated on Reef Island, $6 \mathrm{~km}$ to the east of East Limestone Island. The total population of Haida Gwaii is about 250,000 breeding pairs (Rodway 1991).

\section{Chick trapping}

Ancient Murrelet chicks were trapped when they departed from the colony by guiding them to banding stations close to the shore by means of plastic fences (Fig. 1). Six trapping stations, all operated nightly throughout the chick departure period, were used in each year from 1990-2006. After 2006 trapping was carried out only at two stations (F5, F6) until 2010 when it was resumed at all six stations. Dates of starting and ending trapping in each year were given by Rock and Pattison (2007) up to 2006. Trapping dates during these later years fell within the limits of those during 1990-2006. Chicks were trapped from the time of first departures (22.30-23.30 h, depending on date) onward. Up to 1995, trapping extended until dawn and in those years $94 \% \pm 3 \%$ (SD) were captured before $02.30 \mathrm{~h}$. After 1995 trapping was carried out only up to 02.30 . To allow comparison of chick numbers among years up to and after 1995, we multiplied totals in earlier years by 0.94 . At the end of the season trapping ceased after the first night when no chicks were trapped, although small numbers of departures may have occurred after that date. Captured chicks were weighed, banded, and released to the sea as quickly as possible (usually < 5 min; Gaston 1992, 2003).

The catchment area of the six trapping stations was estimated to intercept approximately $50 \%$ of chicks departing from the colony during the study period. Because trapping methods have remained constant, these records give comparable indices of numbers for the East Limestone Island colony over a 17-year period. The data for F5 and F6 covers 21 years.

\section{Adult captures}

During the period from 1990-2003, adult Ancient Murrelets were captured during the night both before the onset of incubation (about 10 April) and after 20 May, by which time chick departures had begun in all years. In 1990-1994, trapping was conducted by locating birds on the surface with a flashlight or headlight and catching them with handheld dip nets. From 1995, large plastic flight nets, reaching from the ground to about $6 \mathrm{~m}$ high were used to intercept birds departing from the colony from $02.30 \mathrm{~h}$ onward, until dawn. Some birds were also caught with dip nets in 1995, but from 1996-2003 most adults sampled were caught with flight nets, more than $95 \%$ while departing from the colony.

Captured adults were inspected to determine the presence and size of brood patches. Birds with patches $<11 \mathrm{~mm}$ in maximum diameter trapped after 12 May were considered to be nonbreeders, whereas those with brood patches $>19 \mathrm{~mm}$ maximum diameter were considered to be breeders (Gaston 1990). Other birds were considered to be 
Fig. 1. Map showing the location of the study area and the position of chick-capture funnels (numbered) and flight nets on East Limestone Island
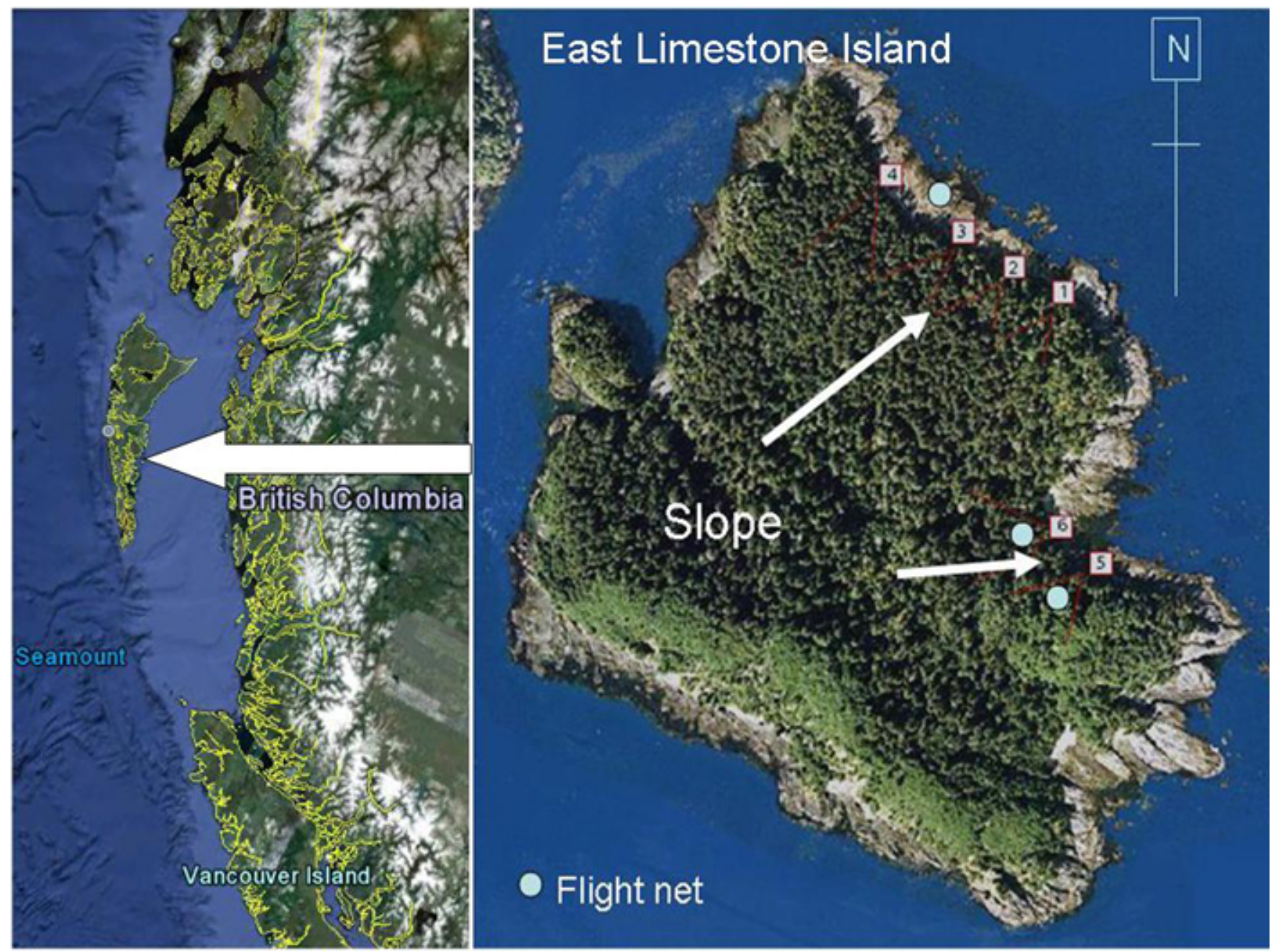

of unknown breeding status and were not included in our results. Nonbreeding birds generally attend the colony in their second and third years to assess and select breeding sites for their first nesting attempt, at three or four years (Gaston 1990). During the 1980s at Reef Island nonbreeders attended the colony irregularly between early May and late June (Jones et al. 1990). We assessed changes in nonbreeders attending the colony from changes in the proportion of nonbreeding birds among adults trapped in flight nets after $02.30 \mathrm{~h}$ from 15 May onward.

\section{Reproductive success}

Following the departure of chicks in 1990, a sample of burrows in two separate areas of the colony was inspected for signs of occupation, i.e., egg shells or membranes. Occupied burrows were numbered and marked for relocation. In succeeding years, the burrow sample was checked daily from 5 April onward to detect the presence of eggs. Additional burrows were located each year and added to the sample to compensate for burrows no longer active. We monitored 12-29 active burrows each year between 1991 and 2003. 
Ancient Murrelets leave the first egg unattended for seven to eight days before laying the second, after which the clutch is incubated more or less continuously (Gaston 1992). Once the first egg was laid a temperature probe was inserted into the nest chamber. Thereafter, the progress of incubation was checked daily by attaching a telethermometer to the temperature probe. After 30 days of incubation, normal incubation period for Ancient Murrelet (Gaston 1992), the burrow was inspected, the contents noted, and the adult and chick(s) banded. The burrow was then inspected daily until the chicks departed, usually within two days. Reproductive success was measured as the number of chicks departing per burrow from burrows where at least one egg was laid.

Breeding failure most often occurred owing to desertion of the clutch. Clutches not being incubated 38 days after the laying of the first egg were removed. The proportion of clutches deserted was also used as a measure of reproductive success.

\section{Estimating the breeding population}

The number of pairs attempting to breed within the catchment area of our funnels was estimated from the number of chicks trapped during each season divided by the estimated mean reproductive success in that year for years 1990-2006 and 2010, when all funnels were operated.

\section{Analysis of survival rates}

Survival analyses were carried out using CaptureMark-Recapture methods (Lebreton et al. 1992), implemented in the software M-SURGE 1.7 (Choquet et al. 2004, 2005). CMR modeling cannot disentangle true survival from permanent emigration so that survival estimates correspond to "apparent survival." Goodness-of-fit (GOF) tests of the Cormack-Jolly-Seber (CJS) model, i.e., the full time dependent model, were performed with the software U-CARE (Choquet et al. 2003, 2009). This test indicates whether or not the "iii" assumption, i.e., independence of fates and identity of rates among individuals, required for CMR analyses, is met by the data.

\section{Details on GOF test}

In a first step, we considered only individuals banded as chicks $(n=7963)$ to estimate survival postdeparture from 1990 to 2003. The fit of CJS model was very poor $\left(\chi^{2}=190.87\right.$, df $=44, P<$ $0.001)$ indicating that the "iii" assumption was not met. This lack of fit was mainly due to test 3.SR ( $\chi^{2}$ $=142.36$, df $=12, P<0.001)$, which tests for transience; a transient individual is an individual leaving the study area permanently after initial capture. This transience is very likely caused by an age effect on apparent survival due to a higher permanent emigration rate (dispersal) after fledging. The sum of the components tests other than test 3.SR, which represents a reduced GOF test for a CJS model in presence of transience (GOF test for a model $\phi_{\mathrm{t}}^{\mathrm{a} 1} \phi_{\mathrm{t}}^{\mathrm{a}>1} p_{t}$ where $\phi_{\mathrm{t}}^{\mathrm{a} 1}$ represents survival of newly marked individuals in the year following capture and $\phi_{t}^{a>1}$ the survival of previously marked individuals from 1 year after capture onward; Pradel et al. 1997, Perret et al. 2003), still indicates moderate lack of fit $\left(\chi^{2}=48.51, \mathrm{df}=32, P=0.031\right)$. Consequently, we opted to apply a variance inflation factor (Lebreton et al. 1992, Burnham and Anderson 2002) calculated as the ratio of the reduced GOF test to its degree of freedom $(c=48.51 / 32=1.52)$, and to base our model selection on QAIC (see Perret et al. 2003 for a similar approach). We started our model selection from a general model including a year and age effect (model $\phi_{t}^{a} 1-2,3,>3 p_{t}^{a 1-2,3,>3}$ ). Considering the very low number of resightings before age 2 , we pooled the first two age classes and only considered the average annual survival from departure to age 2 (noted $\left.a_{1-2}\right)$.

In a second step, we considered data on individuals banded as adults $(n=2368)$ from 1989 to 2003. As previously, the fit of CJS model was very poor $\left(\chi^{2}\right.$ $=171.78, \mathrm{df}=77, P<0.001)$ indicating overdispersion. This lack of fit was mainly due to test 3.SR $\left(\chi^{2}=98.58, \mathrm{df}=13, P<0.001\right)$ and thus to transience. The sum of the components tests other than test 3.SR indicates a good fit $\left(\chi^{2}=73.20, \mathrm{df}=\right.$ $64, P=0.20)$. Consequently, to take into account this transience, we started our model selection from a general model, including a year effect and a twomodality "time-after banding" variable that allows estimating separately the survival rates the year following banding and in subsequent years (model $\left.\phi_{\mathrm{t}}^{\mathrm{a}>1}\right)$.

Matrix demographic model and life-table response experiment (LTRE)

We built a population model to address the issue of which demographic parameter(s) drove the observed decline in this Ancient Murrelet population. LTRE decomposed variation in a 
dependent variable, here the population growth rate, into contributions from differences in the parameters that determine that variable. Here, we considered the variation in population growth rate between two periods: the period 1993-2000 in which the population was rather stable, and the period 2000-2003 in which it was decreasing. We parameterized female-only transition matrices $A$ according to a birth-pulse postbreeding census design (Caswell 2001) for these two periods. These matrices correspond to the life-cycle of ancient murrelets, based on four age-classes: hatchlings, 1year-old individuals, 2-years-old individuals, and adults ( $\geq 3$-years-old):

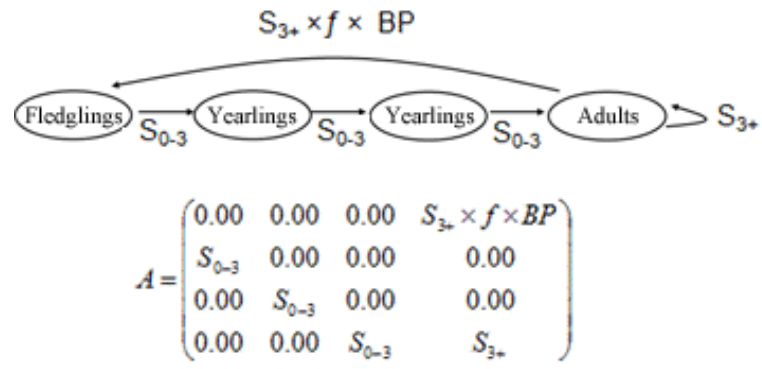

$\mathrm{S}_{3+}$ represents the adult survival (annual survival from 3 years of age onward), $\mathrm{S}_{0-3}$ represents the average annual survival from 0 to 3 years of age, $f$ the fecundity of females $(0.5 \times$ number of departing chicks produced per breeding female), and BP the breeding propensity (probability to breed in a given season, fixed at 1; Gaston 1990). Product SA $\times f \times$ BP represents the fertility $F$ of adult females in a postbreeding census format. The population matrix $A$ projects the population vector $n$ that gives the number of individuals in each age class from time $t$ to $t+1: n_{t+1}=A n_{t}($ Caswell 2001).

Differences in population growth rate $\lambda$ among the two periods considered are the result of all changes in survival and reproductive parameters. Retrospective, or LTRE, analyses decompose those differences in growth rates into contributions from differences in each vital rate (Caswell 2000, 2001). Thus, LTRE analyses give the effects on the change in $\lambda$ of changes in parameter values between the two periods considered. The contribution $C_{i, j}$ of parameter $a_{i, j}$ to change in $\lambda$ is the product of the change in value of this parameter between the two periods considered and of the sensitivity of $\lambda$ to this parameter:

$$
C_{i, j}=\left(a_{i, j p e r i o d 2}-a_{i, j p e r i o d} 1\right) \cdot \frac{\partial \lambda}{\partial a_{i, j}}
$$

A given parameter can thus have a large contribution to changes in $\lambda$ if it changed a lot between the periods considered and/or if the sensitivity of $\lambda$ to this parameter is large. To determine the contributions of the different parameters, the sensitivities were calculated using a mean matrix $A$, whose entries were the averaged values of vital parameters for the two periods considered.

\section{Observations of raccoons}

The presence or absence of raccoons on the Ancient Murrelet colony at East Limestone Island was noted annually by the Laskeek Bay Conservation Society, on the basis of surveys for predation remains and scats conducted systematically two to three times per season. In addition, in 1990 and 1991 an intensive survey of raccoons on the island and adjacent shorelines of nearby Louise Island was carried out throughout the season (Hartman et al. 1997). In the winter of 1991-1992 raccoons were eradicated from East Limestone Island and culled from the adjacent shores of Louise Island (Hartman et al. 1997). On the basis of this information we defined four periods: (1) a period of heavy raccoon disruption in 1990-1991 when much excess killing was noted (Hartman et al. 1997); (2) a period of lower raccoon disturbance between 1992-1995 when raccoons were present intermittently but the scale of killing was small; (3) 1995-2000, when raccoons were not detected; and (4) 2000-2010, when raccoons were again present intermittently, but killing of Ancient Murrelets was on a much smaller scale than in 1990-1991.

\section{RESULTS}

\section{Trends in numbers of chicks}

The highest number of chicks was trapped in 1990, the first year of operation, and the lowest in 2010 (Fig. 2). Overall, there was a negative trend of numbers with year (adjusted $\mathrm{R}^{2}=0.46, P=0.002$ ). During the period post-1991 trends were downward for all capture funnels and significantly negative for funnels 2,5 , and 6 (Table 1 ). Trends in numbers of chicks departing differed among the four periods defined on the basis of raccoon activity: (1) the 
period of heavy raccoon disruption in 1990-1991 was associated with a decrease in total captures of $22 \%$ ( $-11.6 \%$ annually); (2) the period of lower raccoon disturbance between 1992-1995 saw a further $18 \%$ reduction (-6.4\% annual); (3) the period from 1995-2000, when raccoons were not detected, was associated with a small increase (total 14\%; $2.6 \%$ annually), but the trend was not significant (regression $P=0.3$ ); (4) from 2000-2010, during which periodic raccoon predation occurred, numbers decreased significantly, by $58 \%(-8.3 \%$ annually; $\mathrm{R}^{2}=0.46, P=0.02$ ).

\section{Reproductive success}

The number of chicks departing per occupied nest declined significantly over the study period (adjusted $\mathrm{R}^{2}=0.38, P=0.01$ ) while the number of clutches deserted rose (adjusted $\mathrm{R}^{2}=0.45, P<0.01$; Fig. 3). During 1991-1999 the number of chicks departing per nest averaged $1.49 \pm 0.25$ (SE) chicks without any clear trend $(1.57 \pm 0.11[\mathrm{SE}]$ if the El Niño-Southern Oscillation [ENSO] year of 1998 is omitted). From 2000-2003 the average was 1.10 $\pm 0.15 \mathrm{chicks} /$ nest. Hence, reproductive success during 2000-2003 averaged only about $70 \%$ of the level characteristic of the preceding decade. Comparison with similar data collected at Reef Island in 1984-1989 (Gaston 1992) suggests that reproductive success at East Limestone Island during 1991-1999 was similar to that at Reef Island, but during 2000-2003 it was generally lower (Fig. $3)$.

\section{Trend in numbers of breeding pairs}

Estimates of breeding pairs followed similar trends to those seen in chick captures, with an increasing trend from 1995-2000 followed by a steep decline thereafter (Fig. 2). If reproductive success during 2004-2009 was lower than earlier, the trend in numbers of breeding pairs may have been less steep than is indicated by Figure 2.

\section{Nonbreeding adults in the trapped sample}

There was a general decline in the proportion of nonbreeders among adults trapped over the study period $\left(\mathrm{R}^{2}=0.67, P=0.004\right)$, but the most striking change came in 2001. The proportion of nonbreeders trapped in 2001-2003 averaged only 42\%: a little over half the average for the preceding nine years (Fig. 4).

\section{Survival}

\section{Juvenile survival modeling}

Recapture probability for murrelets banded as chicks varied little with time (model 16 vs. 21, model 17 vs. 20; Appendix 1), but varied with age (model 16 vs. 17, model 21 vs. 26; Appendix 1), and was equal to $0.001 \pm 0.0002(\mathrm{SE}), 0.070 \pm 0.05$, and $0.22 \pm 0.04$ at 1,2 , and $\geq 3$ years of age respectively (estimates from best model in Appendix 1).

Survival from departure was also age-dependent and average annual survival between 0 and 2 years old was not different from survival between 2 and 3 years of age (model 5 vs. 8, 10 vs. 12, 14 vs. 16; Appendix 1; average of $0.26 \pm 0.07$ (SE), 0.24 \pm 0.14 , and $0.75 \pm 0.05$ for the apparent annual survival from departure to age 2, from age 2 to age 3 , and from age 3 onward, respectively). From 3 years of age onward, annual apparent survival was constant between 1990 and 2003 (model 5 vs. 7, 5 vs. 9, or 5 vs. 13; Appendix 1). Average survival from departure to age 3 decreased by $\sim 50 \%$ after 2000 (average estimated survival for period 1990-2000 and 2000-2003, respectively: 0.27 \pm 0.02 (SE) and $0.14 \pm 0.04$; model 1 vs. 5 ; Appendix 1, Fig. 5). Between 1990 and 2000, post departure survival was relatively stable, except for periods 1991-1992 and 1996-1997 when it seems to have been elevated (Fig. 5). However, considering the large confidence intervals around these estimates, such changes in average survival rates are difficult to interpret.

\section{Adult survival modeling}

Apparent adult survival was a function of the time after banding, with survival in the year following first capture being lower than in the following years (model 2 vs. 14; Appendix 2, Fig. 6; average apparent survival in the year following first capture: $0.43 \pm 0.02 \mathrm{SE}$; average apparent survival in subsequent years: $0.73 \pm 0.01 \mathrm{SE}$ ). Survival in the year following first capture and survival in subsequent years did not vary in parallel (model 2 vs. 3; Appendix 2). Adult apparent survival exhibited large yearly variation that cannot be 
Fig. 2. Total chicks captured in all funnels at East Limestone Island during 1990-2010 (corrected for years before 1996); total chicks captured in funnels 5 and 6 and estimated size of breeding population within the catchment area (years for which breeding success was available only).

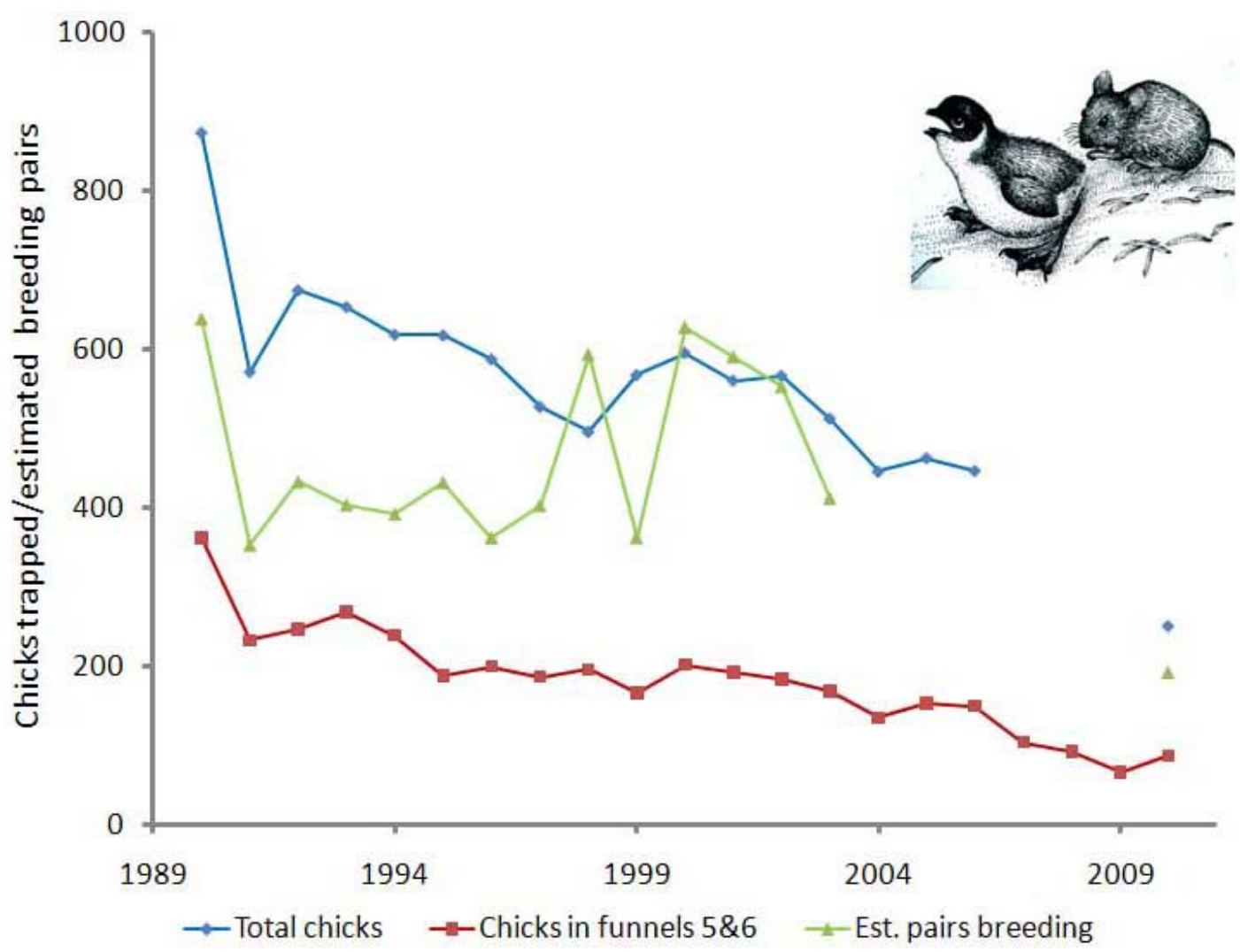

adequately modeled by a linear trend (model 2 vs. 5 and model 2 vs. 7; Appendix 2). However, a linear trend for the survival in the year following first capture was preferred over a constant survival (model 7 vs. 9; Appendix 2). This model indicates that adult apparent survival in the year after first capture decreased by $\sim 60 \%$ over the period 1989-2003 (Appendix 2, Fig. 6). A linear effect explained $33 \%$ of the amount of temporal variance in survival in the year after first capture (calculated as $\left(\operatorname{Dev}_{c s t}-\operatorname{Dev}_{\text {linear }}\right) /\left(\operatorname{Dev}_{c s t}-\operatorname{Dev}_{t}\right)$, where $D e v_{c s t}$ represents the deviance of model $\phi^{a} 1 \phi^{a>} 1 p_{t}$, $D e v_{\text {linear }}$ the deviance of model $\phi^{a} 1_{\text {linear }} \phi^{a>} 1 \dot{p}_{t}$, and Dev $v_{t}$ the deviance of model $\left.\phi^{a} 1_{\text {linear }} \phi^{\dot{a}>} 1 p_{t}\right)$. An analysis of deviance (ANODEV; see Grosbois et al. 2008 for details) indicates that this linear effect is significant $\left(\mathrm{F}_{1,10}=5.53, P=0.038\right)$. Because we have no evidence of a decrease in survival after the first year following capture we take this trend to indicate an increase in transience among our sample.

Contributions of changes in demographic parameters to changes in annual population growth rate

Based on the previous reproductive and survival estimates for adult (one year after capture onward) and juveniles (average survival from departure to age 3 ), we found that annual population growth rate $(\lambda)$ for periods $1990-2000$ and 2000-2003 were 0.750 and 0.730 , respectively. Even when considering the upper limit of the $95 \%$ confidence intervals for adult and juvenile survival, the annual growth rate was far below 1 in period 1990-2000 $(\lambda$ $=0.78$ ). Consequently, population should have declined drastically even in period 1990-2000 (25\% 
Table 1. Results of regression analyses for numbers trapped on year, including and excluding 1990 and 1991.

\begin{tabular}{|c|c|c|c|c|c|c|c|c|}
\hline \multirow[t]{2}{*}{ Funnel } & \multicolumn{4}{|c|}{ All years } & \multicolumn{4}{|c|}{ Years from 1992-2006 } \\
\hline & $\begin{array}{l}\text { Regression } \\
\text { coefficient }\end{array}$ & $\underset{(1,15)}{F}$ & $\underset{\mathrm{R}^{2}}{\text { Adjusted }}$ & $P$ & $\begin{array}{l}\text { Regression } \\
\text { coefficient }\end{array}$ & $\underset{(1,13)}{F}$ & Adjusted $\mathrm{R}^{2}$ & $P$ \\
\hline 1 & 0.57 & 1.61 & & $>0.1$ & 0.08 & 0.08 & & $>0.1$ \\
\hline 2 & -0.63 & 9.80 & 0.35 & 0.01 & -0.75 & 16.92 & 0.53 & 0.001 \\
\hline 3 & -0.30 & 1.53 & & $>0.1$ & -0.17 & 0.39 & & $>0.1$ \\
\hline 4 & -0.41 & 3.08 & & 0.10 & -0.43 & 3.00 & & $>0.1$ \\
\hline 5 & -0.86 & 44.54 & 0.73 & $<0.001$ & -0.89 & 48.01 & 0.77 & $<0.001$ \\
\hline 6 & -0.81 & 29.17 & 0.64 & $<0.001$ & -0.83 & 28.56 & 0.66 & $<0.001$ \\
\hline Total & -0.70 & 14.59 & 0.46 & 0.002 & -0.78 & 19.89 & 0.57 & $<0.001$ \\
\hline
\end{tabular}

per year), which was obviously not the case. Assuming that our estimates of apparent survival and reproduction were correct, these findings suggest that immigration of Ancient Murrelets to East Limestone Island was very important for the dynamics of this colony.

Population growth rate declined after 2000, but by less than $3 \%$. The decrease in juvenile survival explained $90 \%$ of this decline in growth rate (the decrease in breeding success $10 \%$ ), but the effect of such a decline on the population dynamics seems minimal when compared with the very low value of $\lambda$. The annual adult survival rate needed to have a stable population in period 1990-2000 would be 0.987 , clearly highly improbable (e.g., Gaston 2004), but even assuming such a survival rate, the population growth rate in 2000-2003 would be equal to 0.99 meaning that the Ancient Murrelet colony would still be roughly stable despite the decrease in juvenile survival after 2000. Consequently, it seems very unlikely that the decrease in juvenile survival after 2000 could explain the decrease in population size, and a decrease in immigration rates seems more likely.

\section{DISCUSSION}

Most Ancient Murrelets begin to visit breeding colonies at 2 years old and most nonbreeders captured are probably 2 - and 3-year-olds. Most birds are breeding by 4 years of age (Gaston 1990). The majority of birds killed by predators on the colony are typically prebreeders (Gaston 1992). In 1991, raccoon predation on adult birds at East Limestone Island was heavy (Hartman et al. 1997). An abrupt reduction in chick departures in 1991, compared with 1990, probably was associated with disturbance and mortality from raccoon activity. Likewise, the increase in 1992 probably represents a recovery, as pairs that had failed in 1991 because of raccoon disturbance returned to normal levels of reproductive success. Raccoon predation continued at a lower level until at least 1994, after which raccoons were absent, except in 2001 and 2008 and possibly in 2002 (Laskeek Bay Conservation Society, unpublished data). The continued decline after the major raccoon eradication in the winter of 1991-1992 may have been due to continued lowlevel disturbance by raccoons, or to a lack of recruiting breeders of the 3-4 year age classes, discouraged as 2-3-year-olds by the major raccoon disturbance in 1991. From 1995-2000 the population appears to have shown a modest recovery, despite a strong ENSO event in 1998, which caused significantly lowered reproductive 
Fig. 3. Deviations from mean annual reproductive success at Reef Island and East Limestone Island during 1988-2003 (data for Reef Island from Gaston 1990).

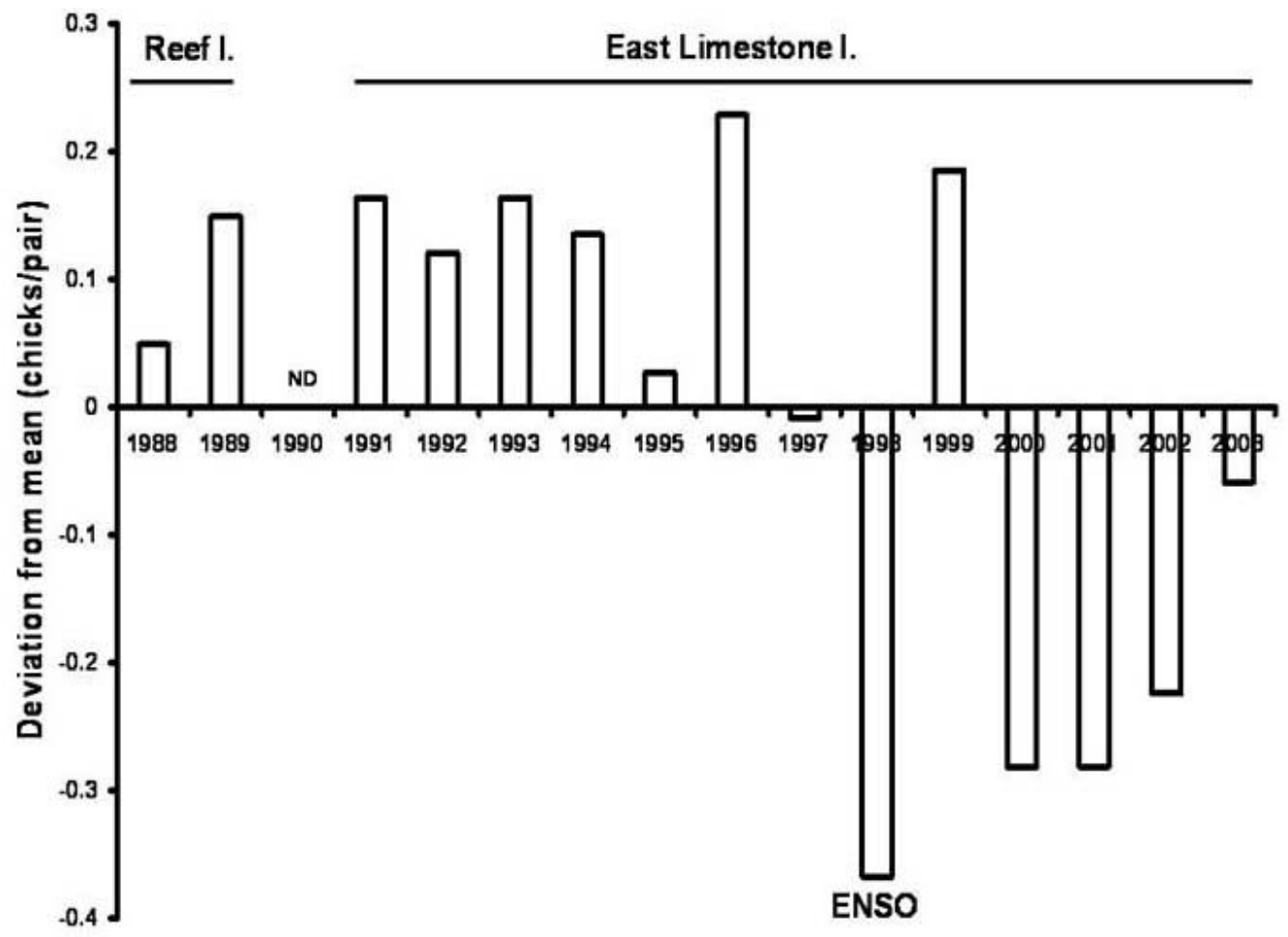

success at East Limestone Island (Gaston and Smith 2001). There was a sharp decrease in numbers of chicks captured in 2003 and 2004 and this decline continued up to 2010 (Fig. 2).

Estimates of total numbers of occupied burrows on East Limestone Island were carried out in 1989, 1995, and 2006 by means of quadrat counts. Based on these estimates, the change of $-21 \%$ between 1989 and 1995 (Lemon 2007) was slightly less than the change in chick numbers from 1990-1995 $(-29 \%)$. The change from 1995-2006 $(-60 \%)$ was considerably higher than the change in chicks captured over the same period $(-28 \%)$. It is possible that numbers of birds breeding outside our catchment area decreased faster during 1995-2006 than those breeding within it. If so, it suggests that our trapping activities were not responsible for declines within our area of operation.

After 2000, and especially after 2002, the observed decline in chick numbers was accompanied by a reduction in apparent survival of first year birds $(2000,2001)$, in reproductive success and in the proportion of nonbreeding birds among the sample of adults trapped after 20 May (Figs. 4-5). All these observations suggest that declines after 2000 had a different cause from earlier declines, probably a consequence of reduction in recruitment to the breeding population. The decline was seen at all funnels and hence must have been more or less colony-wide. Probably nonbreeders trapped at the end of the breeding season are mainly birds prospecting breeding sites for the following year. Hence a reduction in the proportion of prospectors is likely to be a precursor to a reduction in the recruitment of breeders: that is exactly what we observed. Anecdotal observations of a sharp decrease in the level of vocalizations at night after 2001 (Laskeek Bay Conservation Society, unpublished data) also support this idea. In addition, as first-time breeders generally lay later than experienced birds, the idea of reduced recruitment is supported by an earlier cessation of chick 
Fig. 4. Proportion of nonbreeders among adult Ancient Murrelets (Synthliboramphus antiquus) trapped on East Limestone Island after 02.30 h from 15 May - 15 June during 1992-2003.

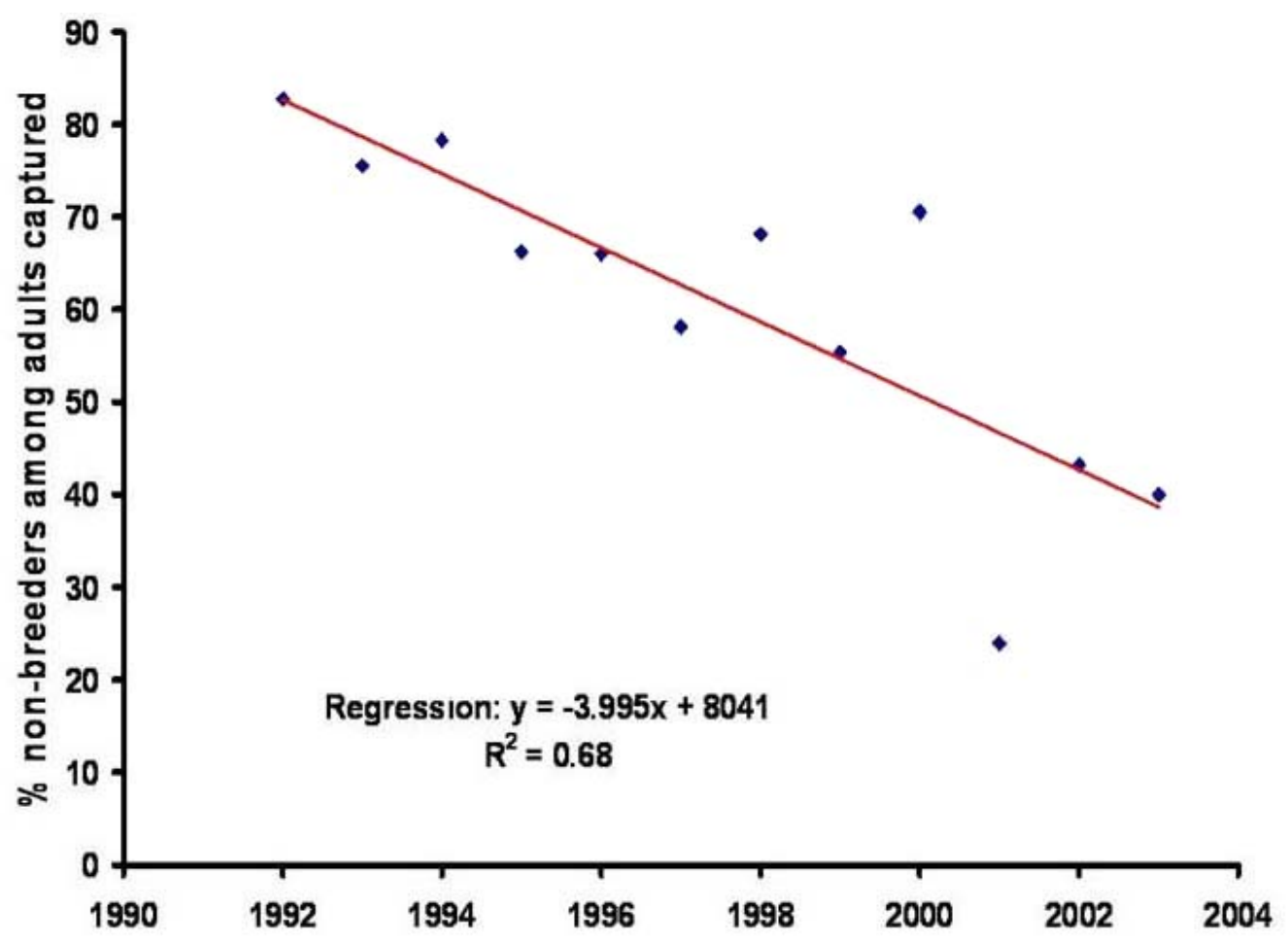

departures in recent years (Laskeek Bay Conservation Society, unpublished data).

Reproductive success in study burrows remained fairly constant or fell slightly during 1991-1997. During this period it was similar to success observed at Reef Island in the 1980s (Gaston 1992). It fell sharply in response to the 1998 ENSO event and recovered in 1999. From 2000-2003 it was 30\% lower than during earlier non-ENSO years. Data were not available after 2003 (monitoring was eliminated to reduce disturbance to the colony). The reduction in reproductive success seems to have been caused principally by an increase in desertions, suggesting either that feeding conditions were poor, so that birds could not maintain a normal incubation schedule, or that predation on breeding adults had increased, either killing them or causing them to desert. Reduced reproductive success at East Limestone Island also may have contributed to the lower numbers of recruits attending the colony after 2000.
The apparent survival rate of first year birds during the early years of the study, at $\sim 0.05-0.10$ (based on annual survival to $2 \mathrm{yr}$ of $\sim 0.27$; Fig. 5 ), was much lower than comparable data for other auk species (Thick-billed Murre Uria lomvia 0.5 [Gaston et al. 1994], Common Murre Uria aalge 0.56 [Harris et al. 2007], Razorbill Alca torda 0.38 [Chapdelaine 1997], Tufted Puffin Fratercula cirrhata 0.08-0.43 [Morrison et al. 2009]), suggesting that only a minority of chicks reared at East Limestone Island returned there as prospectors. This is emphasized by our model estimate of $\lambda=$ 0.75 , assuming no immigration, for the period 1990-2000. Although the population diminished during that period it did not diminish by the overall $95 \%$ expected if $\lambda$ had remained at 0.75 for 10 years. Widespread colony interchange is consistent with the lack of local genetic structuring in this species (Pearce et al. 2002) and with numerous observations of intercolony movements between the East Limestone colony and the nearby colony on Reef Island (Gaston and Adkins 1998). For the larger 
Fig. 5. Average annual apparent survival from chick departure to 3 years of age (dotted lines represent $95 \%$ confidence intervals). Solid lines shows the estimated values based on a model with constant survival for periods 1990-2000 and 2000-2003 (95\% confidence intervals around survival estimates for periods 1990-2000 and 2000-2003, respectively : [0.23, 0.31] and [0.07, 0.24]).

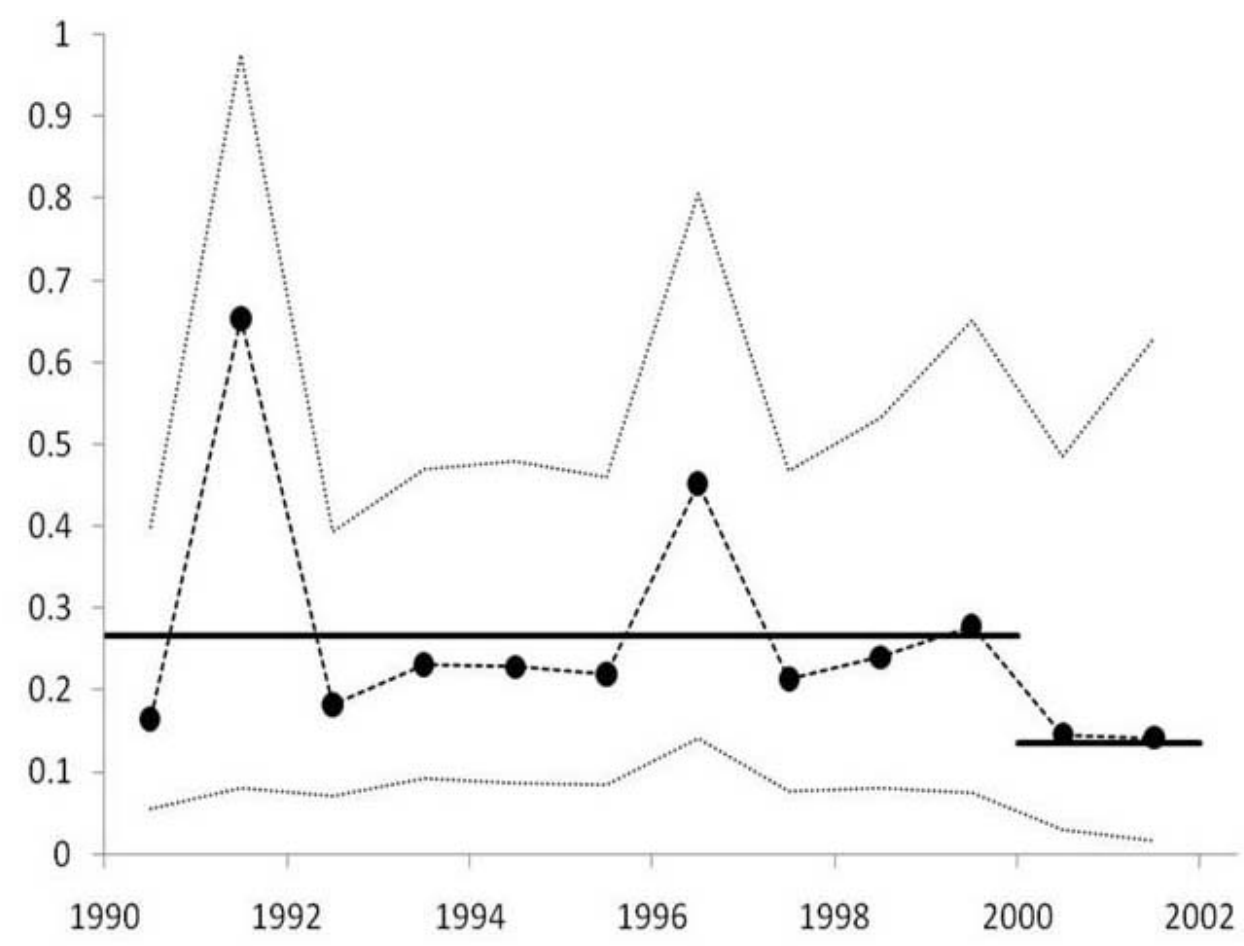

colony at nearby Reef Island Gaston (1990) estimated that $\sim 80 \%$ of recruits came from other colonies.

The apparent survival rate of 0.73 for adults trapped more than one year after banding did not show any trend during the study and was a little lower than that observed at Reef Island in the 1980s (0.77; Gaston 1990), although the earlier estimate falls within the current $95 \%$ confidence limits. The decreasing apparent survival of adult birds during the first year after banding is consistent with the possibility that this fraction of the population comprised visiting prospectors that did not stay to breed and that the likelihood of these birds recruiting locally fell over the period of the study. The apparent survival rates of birds banded as chicks and the number of chicks reared per pair fell after 1999 , perhaps contributing to the reduction in the numbers of prebreeders captured after 2001 and the accelerated rate of population decline. However, as the matrix model results show, these local effects are probably less important than the decline in recruitment from elsewhere.

Observations of predation signs did not suggest increased raccoon activity during the period of the study, but predation by native predators continued to be high (Lemon 2007). As noted above, the total number of breeding pairs on East Limestone Island fell from an estimated 1273 in 1995 to 509 in 2006 (Lemon 2007). Over the same period the local population of ravens (1 pair) and bald eagles (2 pairs) remained stable (Laskeek Bay Conservation Society, unpublished data). The number of predation remains of adult murrelets estimated to be present on the island in 2006 (602) was very similar to numbers estimated in 1995 (619), suggesting that predation pressure on birds attending the colony increased substantially over the period (Lemon 2007). 
Fig. 6. Apparent survival in the year after banding for Ancient Murrelets (Synthliboramphus antiquus) breeding at East Limestone Island (dotted lines represent 95\% confidence). The solid line shows the predicted survival in the year following initial capture based on a model that constrained the relationship between year and survival to be linear (on a logit scale).

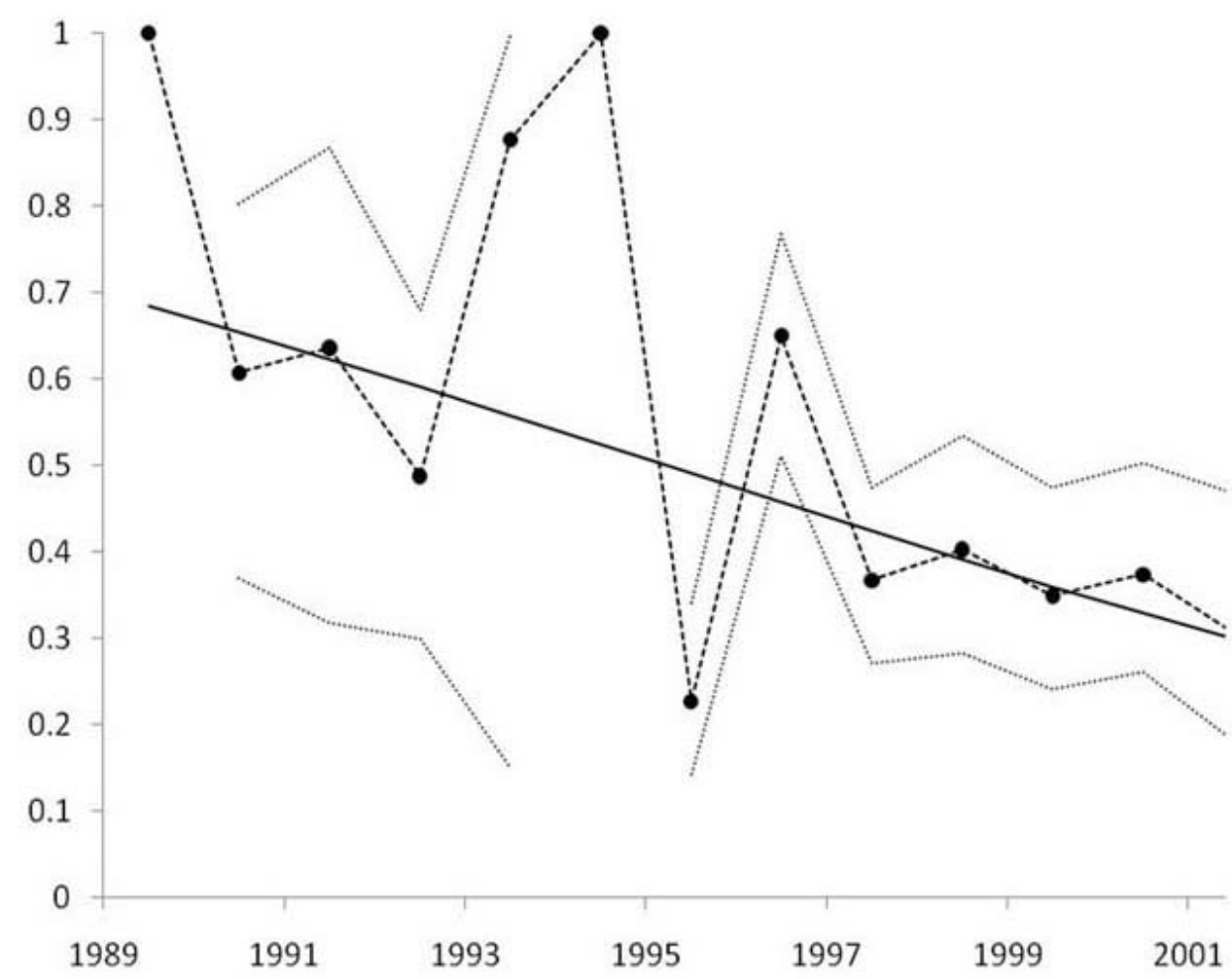

The relative stability of adult survival up to 2002 suggests that the observed population trend was driven by recruitment of new breeders. Our estimates of declining apparent survival in the first year after capture, presumably caused by increasing transience, and our observations of reduced proportions of nonbreeders among adults trapped after 2000, supports this interpretation. Given the relatively small proportion of chicks recruiting to their natal colony, a decline in outside recruitment must be more important than local reproduction and philopatric recruitment in determining colony dynamics at East Limestone Island, and perhaps, given the high incidence of intercolony movement suggested by molecular data (Pearce et al. 2002), in the species as a whole. Consequently, the recruitment decisions of birds reared elsewhere appear to be a critical factor in determining colony dynamics. In the case of East Limestone Island, the increased risk of predation from natural and introduced predators may have played a role in dissuading individuals from recruiting to the colony. It is possible that after 2000 the population had fallen below a critical point where predation by opportunistic predators that can easily switch prey, including the native avian predators, was unsustainable. If that is the case, the local extirpation of the Ancient Murrelet population on East Limestone Island appears likely within the next few decades unless other demographic processes intervene, or a recovery program is initiated.

Responses to this article can be read online at: http://www.ace-eco.org/vol6/iss2/art5/responses/ 


\section{Acknowledgments:}

We are very grateful to the numerous volunteers and directors of the Laskeek Bay Conservation Society, as well as to the professional field staff (J. Brown, S. Charest, L. Cowen, C. French, V. French, J. Gray, K. Heise, A. Lawrence, J. Pattison, J. Rock) for their hard work and dedication in collecting the data on which this study is based. Thanks also to Greg Martin, Lisa McKnight-Yeates, Christine Pansino and Barb Rowsell for all sorts of assistance with management of the field programme. Acknowledgement for the numerous donors supporting Laskeek Bay Conservation Society activities can be found at http://www.laskeekbay.org/sponsors.html

\section{LITERATURE CITED}

Burnham, K. P., and D. R. Anderson. 2002. Model selection and multimodel inference: a practical information-theoretic approach. Second Edition. Springer-Verlag, New York, New York, USA.

Caswell, H. 2000. Prospective and retrospective perturbation analyses: their roles in conservation biology. Ecology 81:619-627. http://dx.doi.org/10.1 890/0012-9658(2000)081[0619:PARPAT]2.0.CO;2

Caswell, H. 2001. Matrix population models: construction, analysis, and interpretation. Second Edition. Sinauer Associates, Sunderland, Massachusetts, USA.

Chapdelaine, G. C. 1997. Pattern of recoveries of banded Razorbills (Alca torda) in the western Atlantic and survival rates of adults and immatures. Colonial Waterbirds 20:47-54. http://dx.doi.org/10 $\underline{.2307 / 1521763}$

Choquet, R., J. D. Lebreton, O. Gimenez, A. M. Reboulet, and R. Pradel. 2009. U-CARE: Utilities for performing goodness of fit tests and manipulating CApture-REcapture data. Ecography 32:1071-1074. http://dx.doi.org/10.1111/j.1600-05 87.2009.05968.x

Choquet, R., A.-M. Reboulet, R. Pradel, O. Gimenez, and J.-D. Lebreton. 2003. User's manual for U-CARE. Mimeographed document, CEFE/ CNRS, Montpellier, France. [online] URL: ftp://ftp .cefe.cnrs.fr/

Choquet, R., A.-M. Reboulet, R. Pradel, O. Gimenez, and J.-D. Lebreton. 2004. M-Surge: new software specifically designed for multistate capture-recapture models. Animal Biodiversity and Conservation 27:207-215.

Choquet, R., A.-M. Reboulet, R. Pradel, O. Gimenez, and J.-D. Lebreton. 2005. M-SURGE 1.7 User's Manual. CEFE-CNRS, Montpellier, France. [online] URL: ftp://ftp.cefe.cnrs.fr/

Gaillard, J. M., D. Pontier, D. Allainé, J. D. Lebreton, J. Trouvillier, and J. Clobert. 1989. An analysis of demographic tactics in birds and mammals. Oikos 56:59-76. http://dx.doi.org/10.230 $\underline{7 / 3566088}$

Gaillard, J. M., and N. G. Yoccoz. 2003. Temporal variation in survival of mammals: a case of environmental canalization? Ecology 84:3294-3306. http://dx.doi.org/10.1890/02-0409

Gaston, A. J. 1990. Population parameters of the Ancient Murrelet. Condor 92:998-1011. http://dx.d oi.org/10.2307/1368736

Gaston, A. J. 1992. The Ancient Murrelet. T. \& A. D. Poyser, London, UK.

Gaston, A. J. 1994. Status of the Ancient Murrelet, Synthliboramphus antiquus, in Canada and the effects of introduced predators. Canadian FieldNaturalist 108:211-222.

Gaston, A. J. 2003. Influence of chick mass and date of departure from the colony on adult characteristics in Ancient Murrelets (Synthliboramphus antiquus), a precocial seabird. Auk 120:818-826. http://dx.doi. org/10.1642/0004-8038(2003)120[0818:IOCMAD] 2.0.CO;2

Gaston, A. J. 2004. Seabirds: a natural history. Yale University Press, New Haven, Connecticut, USA.

Gaston, A. J., and C. Adkins. 1998. Inter-colony movements of Ancient Murrelets Synthliboramphus antiquus at two adjacent colonies. Laskeek Bay Research 8:13-20. [online] URL: http://www.laske ekbay.org/docs/reports/old/Laskeek_Bay_Research 1997. pdf 
Gaston, A. J., L. N. de Forest, G. Donaldson, and D. G. Noble. 1994. Population parameters of Thickbilled Murres at Coats Island, Northwest Territories, Canada. Condor 96:935-948. http://dx.doi.org/10.2 $\underline{307 / 1369103}$

Gaston, A. J., and J. Smith. 2001. Changes in oceanographic conditions off northern British Columbia (1983-99) and the reproduction of a marine bird: the Ancient Murrelet (Synthliboramphus antiquus). Canadian Journal of Zoology 79:1735-1742.

Goodman, D. 1974. Natural selection and a cost ceiling on reproductive effort. American Naturalist 108:247-268. http://dx.doi.org/10.1086/282906

Grosbois, V., O. Gimenez, J.-M. Gaillard, R. Pradel, C. Barbraud, J. Clobert, A. P. Møller, and H. Weimerskirch. 2008. Assessing the impact of climate variation on survival in vertebrate populations. Biological Reviews 83:357-399. http:/ /dx.doi.org/10.1111/i.1469-185X.2008.00047.x

Harris, M. P., M. Frederiksen, and S. Wanless. 2007. Within- and between-year variation in the juvenile survival of Common Guillemots Uria aalge. Ibis 149:472-481. http://dx.doi.org/10.1111/j.1474-919 $\underline{\text { X.2007.00667.X }}$

Hartman, L., A. J. Gaston, and D. Eastman. 1997. Raccoon predation on Ancient Murrelets on East Limestone Island, British Columbia. Journal of Wildlife Management 61:377-388. http://dx.doi.org $\underline{10.2307 / 3802594}$

Jones, I. L., A. J. Gaston, and J. B. Falls. 1990. Factors affecting colony attendance by Ancient Murrelets (Synthliboramphus antiquus). Canadian Journal of Zoology 68:433-441. http://dx.doi.org/1 $\underline{0.1139 / \mathrm{z} 90-064}$

Lack, D. 1963. Population studies of birds. Blackwells, Oxford, UK.

Lack, D. 1968. Ecological adaptations for breeding in birds. Methuen, London, UK.

Lebreton, J.-D., K. P. Burnham, J. Clobert, and D. R. Anderson. 1992. Modeling survival and testing biological hypotheses using marked animals: a unified approach with case studies. Ecological Monographs 62:67-118. http://dx.doi.org/10.2307/ 2937171
Lemon, M. J. F. 2007. East Limestone Island Ancient Murrelet colony survey, June 2006. Laskeek Bay Research 15:67-86. [online] URL: htt p://www.laskeekbay.org/docs/reports/2006-2007/ Lemon M ELI ANMU colony survey June 2006. pdf

Morrison, K. W., J. M. Hipfner, C. Gjerdrum, and D. J. Green. 2009. Wing length and mass at fledging predict local juvenile survival and age at first return in Tufted Puffins. Condor 111:433-441. http://dx.d oi.org/10.1525/cond.2009.080099

Pearce, R. L., J. J. Wood, Y. Artukhin, T. P. Birt, M. Damus, and V. L. Friesen. 2002. Mitochondrial DNA suggests high gene flow in Ancient Murrelets. Condor 104:84-91 http://dx.doi.org/10.1650/0010-5422 (2002)104[0084:MDSHGF]2.0.CO;2

Perret, N., R. Pradel, C. Miaud, O. Grolet, and P. Joly. 2003. Transience, dispersal and survial rates in newt patchy populations. Journal of Animal Ecology 72:567-575. http://dx.doi.org/10.1046/j.13 65-2656.2003.00726.x

Pradel, R., J. E. Hines, J.-D. Lebreton, and J. D. Nichols. 1997. Capture-recapture survival models taking into account of transients. Biometrics 53:60-72. http://dx.doi.org/10.2307/2533097

Pradel, R., C. M. A. Wintrebert, and O. Gimenez. 2003. A proposal for goodness-of-fit test to the Arnason-Schwarz multisite capture-recapture model. Biometrics 59:43-53. http://dx.doi.org/10.1111/154 1-0420.00006

Regehr, H. M., R. S. Rodway, M. J. F. Lemon, and J. M. Hipfner. 2007. Recovery of the Ancient Murrelet Synthliboramphus antiquus colony on Langara Island, British Columbia, following eradication of invasive rats. Marine Ornithology 35:137-144.

Rock, J., and J. Pattison. 2007. East Limestone Island Field Station: report on the 2007 field season. Laskeek Bay Research 15:15-30. [online] URL: htt p://www.laskeekbay.org/docs/reports/2006-2007/ ELI 2007 Field Season Report.pdf

Rock, J., and J. Pattison. 2008. East Limestone Island Field Station: report on the 2008 field season. 
Laskeek Bay Research 16:1-16. [online] URL: http ://www.laskeekbay.org/docs/reports/2008-2009/ ELI 2008 Field Season.pdf

Rodway, M. S. 1991 Status and conservation of breeding seabirds in British Columbia. Pages 43-102 in J. P. Croxall, editor. Supplement to the status and conservation of the world's seabirds. International Council for Bird Preservation, Cambridge, UK.

Rodway, M. S., M. J. F. Lemon, and G. W. Kaiser. 1988. British Columbia seabird colony inventory Report \#1 - East coast Moresby Island. Canadian Wildlife Service Technical Report 50:1-276.

Saether, B. E., and O. Bakke. 2000. Avian life history variation and contribution of demographic traits to the population growth rate. Ecology 81:642-653. http://dx.doi.org/10.1890/0012-9658(2000) 081[0642:ALHVAC]2.0.CO;2

Sealy, S. G. 1976. Biology of nesting Ancient Murrelets. Condor 78:294-306. http://dx.doi.org/10 $.2307 / 1367688$

Stearns, S. C., and T. J. Kawecki. 1994. Fitness sensitivity of the canalization of life-history traits. Evolution 48:1438-1450. http://dx.doi.org/10.2307 $\underline{12410238}$ 
APPENDIX 1. Modelling of survival ( $\Phi)$ and recapture rates (p) of Ancient Murrelets banded as chicks at East Limestone Island, Canada from 1990 to 2003 as a function of year and age. Superscript $a$ refers to age effects, subscript $t$ to time effects and subscript linear refers to a linear time effect. Note that $\Phi^{a 1-3,>3}$ linear for example is equivalent to $\Phi^{a 1-3}$ linear $\Phi_{\text {linear }}^{a>3}$ (i.e., a linear time effect applied to both age classes but with different slopes and intercepts for each age class). $n p$ represents the number of identifiable parameters for each model, QAIC the Akaike Information Criterion corrected for overdispersion $(\hat{c}=1.52)$ and $\triangle Q A I C$ the difference in $\mathrm{Q} A I C$ values with the model of lowest AIC. + refers to additive age effect, and subscript 90-00,00-03 refers to a two-modality variable constraining survival to be constant in period 1990-2000 and in period 2000-2003.

\begin{tabular}{|c|c|c|c|c|}
\hline$\#$ & Model & $n p$ & QAIC & $\Delta \mathrm{QAIC}$ \\
\hline 1 & $\phi_{90-00,00-03}^{a_{1-3}} \phi^{a_{24}} p^{a_{1,2,23}}$ & 6 & 906.68 & 0.00 \\
\hline 2 & $\phi_{90-00,00-03}^{a_{1-2}} \phi^{a_{3}} \phi^{a_{24}} p^{a_{1,2,23}}$ & 7 & 908.91 & 2.22 \\
\hline 3 & $\phi_{\text {linear }}^{a_{1-3}} \phi^{a_{24}} p^{a_{1,2,23}}$ & 6 & 910.02 & 3.34 \\
\hline 4 & $\phi_{90-00,00-03}^{a_{1-2}} \phi_{90-00,00-03}^{a_{3}} \phi^{a_{24}}$ & 8 & 910.49 & 3.81 \\
\hline & $p^{a_{1,2, \geq 3}}$ & & & \\
\hline 5 & $\phi^{a_{1-3,24}} p^{a_{1,2,23}}$ & 5 & 911.72 & 5.03 \\
\hline 6 & $\phi^{a_{1-2}} \phi_{90-00,00-03}^{a_{3}} \phi^{a_{24}} p^{a_{1,2,23}}$ & 7 & 913.31 & 6.63 \\
\hline 7 & $\phi^{a_{1-3}} \phi_{\text {linear }}^{a_{24}} p^{a_{1,2,23}}$ & 6 & 913.37 & 6.69 \\
\hline 8 & $\phi^{a_{1-2,3,24}} p^{a_{1,2,23}}$ & 6 & 913.70 & 7.02 \\
\hline 9 & $\phi^{a_{1-3}} \phi_{90-00,00-03}^{a_{24}} p^{a_{1,2,23}}$ & 6 & 920.82 & 14.14 \\
\hline 10 & $\phi_{t}^{a_{1-3,24}+} p^{a_{1,2,23}}$ & 17 & 921.22 & 14.54 \\
\hline 11 & $\phi_{t}^{a_{1-3}} \phi^{a_{24}} p^{a_{1,2,23}}$ & 17 & 922.30 & 15.62 \\
\hline 12 & $\phi_{t}^{a_{1-2,3,24^{+}}} p^{a_{1,2,23}}$ & 18 & 923.31 & 16.63 \\
\hline
\end{tabular}




\begin{tabular}{|c|c|c|c|c|}
\hline 13 & $\phi^{a_{1-3}} \phi_{t}^{a_{24}} p^{a_{1,2,23}}$ & 14 & 924.34 & 17.66 \\
\hline 14 & $\phi_{t}^{a_{1-3,24}} p^{a_{1,2,23}}$ & 26 & 935.33 & 28.65 \\
\hline 15 & $\phi_{\text {linear }}^{a_{1-3}} \phi_{\text {linear }}^{a_{24}} p^{a_{1,2,23}}$ & 7 & 942.82 & 36.14 \\
\hline 16 & $\phi_{t}^{a_{1-2,3,24}} p^{a_{1,2,23}}$ & 37 & 943.25 & 36.56 \\
\hline 17 & $\phi_{t}^{a_{1-2,3,24}} p^{a_{1,22}}$ & 36 & 946.59 & 39.90 \\
\hline 18 & $\phi_{t}^{a_{1-2,3,24}} p_{t}^{a_{1-2,23}+}$ & 49 & 959.69 & 53.01 \\
\hline 19 & $\phi_{t}^{a_{1-2,3,24}} p_{t}^{a_{1,22}+}$ & 48 & 959.73 & 53.05 \\
\hline 20 & $\phi_{t}^{a_{1-2,3, \geq 4}} p_{t}^{a_{1,22}}$ & 56 & 971.77 & 65.09 \\
\hline 21 & $\phi_{t}^{a_{1-2,3,24}} p_{t}^{a_{1,2, \geq 3}}$ & 64 & 974.01 & 67.33 \\
\hline 22 & $\phi_{t} p^{a_{1,2,23}}$ & 16 & 975.38 & 68.69 \\
\hline 23 & $\phi_{t}^{a_{1-2,3,24}} p_{t}^{a_{1,2,3,24}}$ & 71 & 978.57 & 71.88 \\
\hline 24 & $\phi_{t}^{a_{1-2,3,24}} p_{t}^{a_{1-2,3,24}}$ & 65 & 1007.82 & 101.14 \\
\hline 25 & $\phi_{t}^{a_{1-2,3,24}} p_{t}^{a_{1-3,24}}$ & 55 & 1044.46 & 137.78 \\
\hline 26 & $\phi_{t}^{a_{1-2,3,24}} p_{t}$ & 46 & 1045.01 & 138.33 \\
\hline
\end{tabular}


Appendix 2. Modelling of survival $(\phi)$ and recapture rates (p) of Ancient Murrelets banded as adults at East Limestone Island, Canada from 1989 to 2003 as a function of year, and time after banding. Superscript " $a_{1,>1}$ " refers to the time after banding (year after banding and subsequent years), subscript " $t$ " to the year effect and subscript " 89 $00,00-03$ " to a two modality variable where survival is constant in periods 1989-2000 and 200-2003). Note that model $\phi_{t}^{a_{1,>1}}$ for example is equivalent to model $\phi_{t}^{a_{1}} \phi_{t}^{a_{>1}}$. Our initial model was $\phi_{t}^{a_{1,1}} p_{t}^{a_{1,>1}}$ and we started to model recapture, and then survival rates. $n p$ represents the number of identifiable parameters for each model, AIC the Akaike Information Criterion and $\triangle A I C$ the difference in $A I C$ values with the model of lowest AIC. + refers to additive « time after banding » effect and subscript 89-00,00-03 refers to a two-modality variable constraining survival to be constant in period 1989-2000 and in period 2000-2003.

\begin{tabular}{|c|c|c|c|c|}
\hline$\#$ & Model & $\mathrm{np}$ & AIC & $\Delta \mathrm{AIC}$ \\
\hline 1 & $\phi_{t}^{a_{1,>1}} p_{t}^{a_{1,>1}+}$ & 41 & 5503.31 & 0.00 \\
\hline 2 & $\phi_{t}^{a_{1,>1}} p_{t}$ & 40 & 5503.36 & 0.05 \\
\hline 3 & $\phi_{t}^{a_{1,>1}+} p_{t}$ & 29 & 5505.98 & 2.67 \\
\hline 4 & $\phi_{t}^{a_{1}} \phi^{a_{>1}} p_{t}$ & 29 & 5509.04 & 5.73 \\
\hline 5 & $\phi_{t}^{a_{1}} \phi_{\text {linear }}^{a>1} p_{t}$ & 30 & 5510.93 & 7.62 \\
\hline 6 & $\phi_{t}^{a_{1}} \phi_{89-00,00-03}^{a>1} p_{t}$ & 30 & 5511.03 & 7.71 \\
\hline 7 & $\phi_{\text {linear }}^{a_{1}} \phi_{t}^{a>1} p_{t}$ & 29 & 5513.76 & 10.44 \\
\hline 8 & $\phi_{89-00,00-03}^{a_{1}} \phi_{t}^{a>1}$ & 29 & 5524.16 & 20.84 \\
\hline 9 & $\begin{array}{cc} & p_{t} \\
\phi^{a_{1}} & \phi_{t}^{a>1} p_{t}\end{array}$ & 28 & 5528.06 & 24.74 \\
\hline 10 & $\phi_{\text {linear }}^{a_{1,>1}} p_{t}$ & 18 & 5549.74 & 46.42 \\
\hline 11 & $\phi_{t}^{a_{1,>1}} p_{t}^{a_{1,>1}}$ & 52 & 5517.76 & 14.44 \\
\hline
\end{tabular}




\begin{tabular}{ccccc}
\hline 12 & $\phi_{89-00,00-03}^{a_{1,>3}} p_{t}$ & 18 & 5560.40 & 57.09 \\
13 & $\phi^{a_{1,>1}} p_{t}$ & 16 & 5561.54 & 58.22 \\
14 & $\phi_{t} p_{t}$ & 27 & 5575.53 & 72.21 \\
15 & $\phi_{t}^{a_{1,1}} p$. & 28 & 5676.80 & 173.48 \\
16 & $\phi_{t}^{a_{1,11}} p^{a_{1,2+}}$ & 29 & 5678.02 & 174.70 \\
\hline
\end{tabular}

